\section{From scientific advances to public health action: the crucial role of science dissemination}

\author{
Fèlix Bosch, ${ }^{1,2}$ Elisabet Serés ${ }^{1}$
}

It is widely accepted that dissemination of research results has received little attention in biomedical journals, and, clearly, a scientific discovery is worthless if not communicated. The method, for example, of isolating insulin developed by Eugène Grey and kept hidden for almost 20 years is noteworthy. In 1905 Grey injected gelatine into the pancreatic duct and waited for the pancreas to degenerate before preparing an extract. ${ }^{1}$ The concept was the same as that of Banting and Best. Had Grey published his results instead of depositing them in a sealed packet at the French Society of Biology until after the work of Banting and Best was published, ${ }^{2}$ the treatment of diabetes might have been advanced by a quarter of a century.

Pharmacology offers many examples of the role of science dissemination, in specialty journals and in the lay press, in the development and adoption of new drugs and on the limitations imposed on their use by notorious public health decisions. An appropriate example is that of arsphenamine-a drug, widely known as Salvarsan, which was developed by Ehrlich in $1910 .^{3}$ This development was possible because Schaudinn and Hoffmann proved, in 1905, that Treponema pallidum was the causative agent of syphilis. ${ }^{4}$ Arsphenamine deserved its description as a 'magic bullet' because it was the first active remedy against the scourge of syphilis. It is not surprising that in 1911 an article in $J A M A^{5}$ claimed that 'Salvarsan is not simply an additional remedy for syphilis; it marks an epoch in medicine' and that the New York Times published 10 articles on this drug in 1910 alone. ${ }^{6}$ The early history of arsphenamine and its derivative neoarsphenamine also illustrates the influence of non-medical factors on the dissemination of a scientific discovery. For example, the political climate in the days before World War I led to strong denials of the worth of these drugs in the French and British media. However, the

${ }^{1}$ Esteve Foundation, Barcelona, Spain; ${ }^{2}$ Department of Experimental and Health Sciences, Universitat Pompeu Fabra, Barcelona, Spain

Correspondence to Dr Fèlix Bosch, Esteve Foundation, Llobet i Vall-Llosera 2, Barcelona, Catalonia 08032, Spain; fbosch@esteve.org values and limitations of these drugs became widely accepted, and by the publication of the first edition of Goodman and Gilman's 'The Pharmacological Basis of Therapeutics' in 1940 their role in the treatment of syphilis had been clearly established.

The use of poisonous gases in World War II also played an important role in another scientific discovery and in hindering its diffusion. In 1919 Krumbhaar and Krumbhaar' $^{7}$ reported that 'Yellow cross or mustard gas exerts on the bone marrow a direct toxic action, which, by depleting the leucocytes of the circulation, has an important bearing on the inability to resist secondary infection'. These observations, as well as the results of experimental animal studies, led in 1942 to the first clinical trial of a mustard gas derivative (a 'nitrogen mustard') for the treatment of lymphomas. Unfortunately, the results could not be published until much later because nitrogen mustards were military classified products. ${ }^{8}$

The path from scientific discovery to public health benefits is often not easy and it is worth considering some of the possible obstacles. Here, the role of scientific journals cannot be ignored. It is shocking to realise that although spirochaetes had been observed in 1940 in the gastric mucosa in autopsies of patients with ulcers, ${ }^{9}$ Warren and Marshall faced serious difficulties in publishing their results on the relationship between Helicobacter pylori and duodenal ulcers, because the bacterial theory of ulcers was viewed as preposterous. One wonders whether the acceptance of their letter to The Lancet in $1983^{10}$ was ultimately due to the idiosyncracy of editorial decisions in this journal at that time. One also wonders why it was not until 1990 that eradication of Helicobacter pylori was fully accepted as a cure for duodenal ulcers. ${ }^{11}$

Researchers may also play a part in the distortion of scientific communication. A review by Stather ${ }^{12}$ examined the substantial impact of an article in the lay press about an American Heart Association conference report on the results of a retrospective, case-control study that suggested that treatment of hypertension with calcium antagonists was associated with a $60 \%$ increase in the risk of myocardial infarction. It is not a minor issue that these results were presented at a press conference at that meeting, during which reporters were told that the study was funded by the University of Washington whereas the funding had come from a pharmaceutical company (which did not market any calcium antagonist).

The positive and negative contributions of the lay press in the dissemination of scientific knowledge have long been discussed. An example of the former is a New York Times article about the putative benefits of some anti-angiogenesis drugs in cancer, which led to a subsequent case study. ${ }^{13}$ Some scientists are irritated by, and even despise, science journalists ${ }^{14}$ but one should remember that some reporters have made major contributions to public health. One such contribution is the crusade by Brian Deer, in the Sunday Times, to expose fraud in the case against the measles, mumps and rubella (MMR) vaccine. ${ }^{15}$ An article in The Lancet (later retracted by the journal) linking MMR vaccines and autism had longstanding negative consequences affecting the attitude of parents towards the recommended vaccination programme. However, thanks largely to Deer's work, this link was shown to be false and thus he made a major contribution to both science and society.

We can see that communication in science has a crucial role in the path from scientific advances to public health action and, clearly, the roles of the different participants in the process should be taken into account. It is not uncommon to discover distortions in manuscripts (for example, by referring only to relative risks and ignoring absolute values) ${ }^{16}$ that may lead to wrong conclusions, and press releases from scientific journals are not always free from propaganda. ${ }^{17}$ Educated and responsible scientific journalism should be fostered and scientists can and should help in this regard. Furthermore, the lack of specific training for $\mathrm{PhD}$ students and health professionals in the skills of scientific communication surely deserves attention.

Acknowledgements We thank Professor Sergio Erill for his help in reviewing the manuscript.

Contributors Both authors planned, drafted and revised the final manuscript.

Competing interests None.

Provenance and peer review Commissioned; externally peer reviewed. 


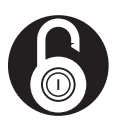

\section{OPEN ACCESS}

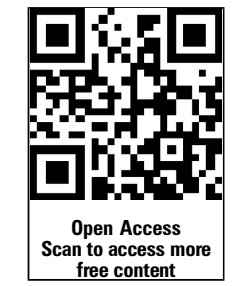

Open Access This is an Open Access article distributed in accordance with the Creative Commons Attribution Non Commercial (CC BY-NC 3.0) license, which permits others to distribute, remix, adapt, build upon this work non-commercially, and license their derivative works on different terms, provided the original work is properly cited and the use is non-commercial. See: http:// creativecommons.org/licenses/by-nc/3.0/

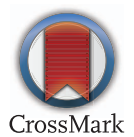

To cite Bosch F, Serés E. J Epidemiol Community Health 2015;69:1-2.

Published Online First 20 June 2014
J Epidemiol Community Health 2015:69:1-2. doi:10.1136/jech-2014-203851

\section{REFERENCES}

Henderson JR. Who discovered insulin? Guy's Hosp Gaz 1971;85:315-8.

2 Banting $\mathrm{FG}$, Best $\mathrm{CH}$. The internal secretions of the pancreas. J Lab Clin Med 1922;7:465-80.

3 Bosch F, Rosich L. The contributions of Paul Ehrlich to pharmacology. A tribute on the occasion of the centenary of his Nobel Prize. Pharmacology 2008;82:171-9.

4 Schaudinn F, Hoffmann E. Vorläutableer Bericht über das Vorkommen von Spirochaeten in syphilitischen Krankheitsprodukten und bei Papillomen. Arb Kaiserlich Gesundheitsamt 1905;22:527-34.

5 Meltzer SJ. The present status of therapeutics and the significance of Salvarsan. JAMA 1911;23:1907-13.

6 Serés $E$, Bosch $F$. Early days of a new chemotherapeutic drug. J Chemother 2010;22:39.

7 Krumbhaar EB, Krumbhaar HD. The blood and bone marrow in yellow cross gas (mustard gas) poisoning: changes produced in the bone marrow of fatal cases. J Med Res 1919;40:497-508.
8 Gilman A, Philips FS. The biological actions and therapeutic applications of the $\beta$-chloroethylamines and sulphides. Science 1946;103:409-15.

9 Freedberg AS, Baron LE. The presence of spirochaetes in human gastric mucosa. Am J Digest Dis 1940;7:443-5.

10 Warren JR, Marshall B. Unidentified curved bacilli on gastric epithelium in active chronic gastritis. Lancet 1983;1:1273-5.

11 Rauws EAJ, Tytgat GNJ. Cure of duodenal ulcer associated with eradication of Helicobacter pylori. Lancet 1990;335:1233-5.

12 Stather R. Learning from controversies in pharmacoepidemiology. Reactions Weekly 1998;722:3-4.

13 Coopera CP, Yukimurab D. Science writers' reactions to a medical "breakthrough" story. Soc Sci Med 2002;54:1887-96.

14 Nelkin D. Selling Science. New York: WH Freeman and Co, 1987.

15 Deer $B$. How the case against the MMR vaccine was fixed. BMJ 2011;342:77-82.

16 Casino G. Producers, communicators and consumers of 'risk'. J Epidemiol Community Health 2010;64:940.

17 Woloshin S, Schwartz LM. Press releases: translating research into news. JAMA 2002;287:2856-8. 